\section{Fenomena Anok Jolanon di Kota Cirebon}

Permasalahan anak jalanan atau pekerja anak merupakan masalah sosial yang belum terselesaikan sampai saat ini. Solusi yang dibuat oleh stakeholders atas permasalahan tersebut masih belum menyentuh akar permasalahan yang sesungguhnya. Permasalahan anak jalanan terkait erat dengan kondisi ekonomi, sosial, dan budaya di dalam keluarga mereka. Desakan ekonomi dalam kehidupan perkotaan di Cirebon menyisakan kelompok masyarakat dengan akses yang serba terbatas.

Penelitian ini berupaya memotret fenomena anak jalanan di Kota Cirebon secara langsung pada dua titik yang selama ini merupakan tempat mereka melakukan aktifitas sehari-hari, mencari nafkah membantu ekonomi keluarga dan bermain dengan teman sebaya atau orang yang lebih dewasa yang juga bekerja dijalanan.

Temuan penelitian menggambarkan kondisi anak jalanan sebagian besar merupakan usia sekolah, bahkan beberapa dari mereka sudah tidak bersekolah lagi (drop out), berasal dari Kota Cirebon $75 \%$ dan Kabupaten Cirebon $25 \%$ dengan aktivitas utama mengamen, mengemis dan berjualan tisu yang dijajakan di perempatan jalan ketika lampu lalulintas sedang merah (berhenti). Sebagian besar anak jalanan pernah mengalami kekerasan fisik sperti :1) ditendang, dicubit, dan diinjak oleh tukang becak, 2) dibenturkan ke pintu oleh orang tuanya, 3) dipukul dan dikeroyok di sekolah oleh temannya, 4) dipaksa jual tisu, 5) dibatasi jam main, karena di terget jualan tisu. Kekerasan Psikologis: 1) dihina, diejek, bullying oleh teman sekolah maupun teman di jalan dan 2) bullying (dimarahi dan direndahkan) di rumah oleh orang tuanya. Alasan ekonomi dan situasi psikologis menjadi alasan anak turun ke jalan, dalam ketidakberdayaan.
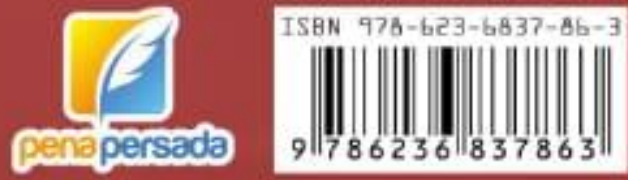

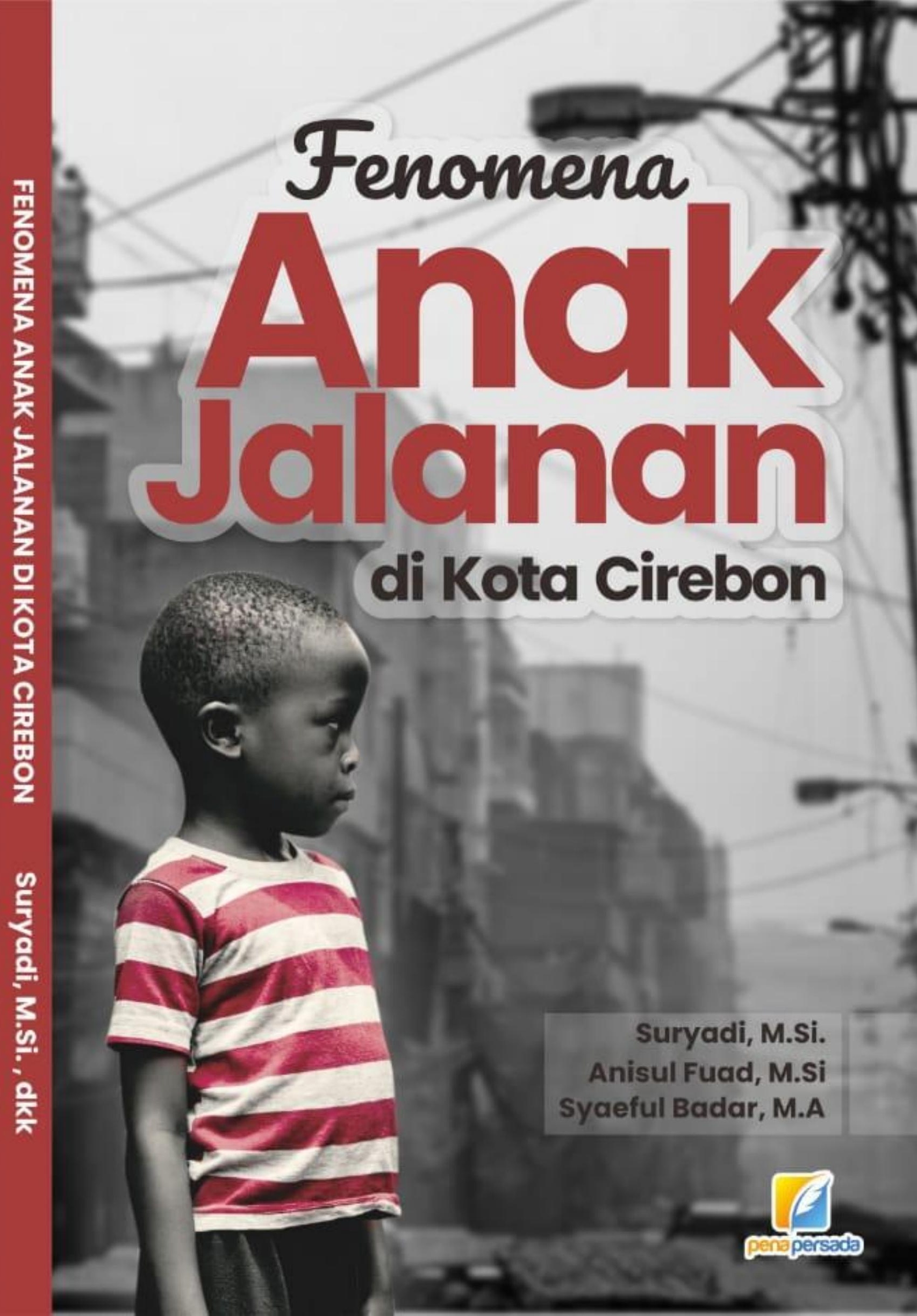




\title{
FENOMENA ANAK JALANAN DI KOTA CIREBON
}

\author{
Suryadi, M.Si. \\ Anisul Fuad, M.Si \\ Syaeful Badar, M.A
}

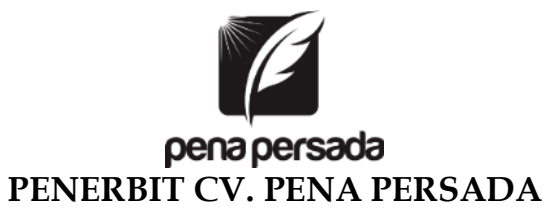




\title{
FENOMENA ANAK JALANAN \\ DI KOTA CIREBON
}

\author{
Penulis: \\ Suryadi, M.Si. \\ Anisul Fuad, M.Si \\ Syaeful Badar, M.A \\ ISBN : 978-623-6837-86-3 \\ Design Cover : \\ Retnani Nur Briliant \\ Layout : \\ Nisa Falahia

\section{Penerbit CV. Pena Persada} \\ Redaksi : \\ Jawa Tengah \\ Email : penerbit.penapersada@gmail.com
}

Jl. Gerilya No. 292 Purwokerto Selatan, Kab. Banyumas

Website : penapersada.com Phone : (0281) 7771388

Anggota IKAPI

All right reserved

Cetakan pertama : 2020

Hak Cipta dilindungi oleh undang-undang. Dilarang memperbanyak karya tulis ini dalam bentuk apapun tanpa izin penerbit 


\section{KATA PENGATAR}

Puji dan syukur peneliti ucapkan kepada Allah Swt., Tuhan Yang Maha Esa karena berkat rahmat dan karunia-Nya penulis dapat menyelesaikan buku ini. Buku ini merupakan hasil penelitian terhadap anak jalanan di kota Cirebon. Penulis memandang penelitian ini penting dilakukan karena untuk mengetahui kondisi yang sesungguhnya. Poin-poin yang hendak diketahui adalah tentang akar permasalahan, potensi solusi, dan model-model pencegahan anak jalanan.

Dengan adanya penelitian ini diharapkan dapat menjadi masukan bagi masyarakat, lembaga yang mempunyai perhatian terhadap anak jalanan. Kemudian, masukan untuk pemerintah Kota Cirebon dalam merumuskan kebijakan. Dengan demikian, permasalahan anak jalanan dapat diatasi atau setidaknya dapat dikurangi, baik dari besaran jumlah mereka dan kompleksitas masalahnya.

Pada kesempatan ini, kami mengucapkan terima kasih kepada TIM LPPM IAIN Syekh Nurjati Cirebon yang telah memberikan kesempatan dan dukungan untuk melakukan penelitian ini sehingga dapat menyelesaikan tugas tersebut pada tahun 2019 dengan baik. Sebagaimana pada tahun-tahun sebelumnya, Laporan Penelitian ini disajikan untuk menyampaikan seluruh kegiatan penelitian dan pengabdian kepada masyarakat yang telah dilaksanakan oleh tenaga pendidik di lingkungan IAIN Syekh Nurjati Cirebon.

Cirebon, Oktober 2020

Tim Peneliti 


\section{DAFTAR ISI}

KATA PENGANTAR ......................................................... iii

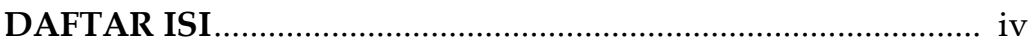

BAB I

MENGENAL LEBIH DEKAT ANAK JALANAN

A. Pembangunan dan Anak Jalanan ............................. 1

B. Anak Jalanan dalam Perspektif Teoretis ..................... 10

C. Metode Penjabaran Wacana ......................................... 32

BAB II

ANAK JALANAN DI TENGAH PEMBANGUNAN KOTA CIREBON

A. Magnet wilayah Ciayumajakuning ............................ 35

B. Kondisi Anak Jalanan di kota Cirebon........................ 37

C. Masalah yang Dihadapi Anak Jalanan di Kota Cirebon............................................................ 39

D. Harapan Para Anak Jalanan........................................ 46

E. Anak Jalanan dalam Sudut Pandang Analisis Sosial .... 47

\section{BAB III}

\section{UPAYA PENANGANAN ANAK JALANAN DI KOTA}

\section{CIREBON}

A. Masukan Para Ahli 49

B. Upaya-Upaya yang dapat dilakukan Pemerintah Kota Cirebon 55

C. Peran Serta Masyarakat .............................................. 60

DAFTAR PUSTAKA ........................................................... 62 


\section{BAB I \\ ANAK JALANAN DI TENGAH \\ GENCARNYA PEMBANGUNAN}

\section{A. Pembangunan dan Anak Jalanan}

Proses pembangunan dalam suatu negara menjadi sebuah hal yang dicermati para pihak. Pemerintah bersama semua komponen bangsa pun bahu-membahu untuk bersama membangun sehingga menjadi negeri yang adil dan makmur. Cita-cita inilah yang menjadi amanat dari UUD 1945 maupun Dasar Negara, Pancasila.

Salah satu sektor dalam pembangunan yang signifikan adalah sektor ekonomi. Pembangunan ekonomi secara garis besar didefinisikan sebagai proses kenaikan pendapatan total dan pendapatan per kapita dengan memperhitungkan pertambahan penduduk. Selain itu, disertai dengan perubahan fundamental dalam struktur ekonomi suatu negara dan pemerataan pendapatan bagi penduduknya.

Namun, dalam prosesnya, pembangunan ekonomi secara merata bukan sesuatu hal yang mudah untuk dicapai. Hal ini sangat beralasan mengingat luas wilayah, besarnya sumber daya, baik alam maupun manusia yang ternyata belum siap. Selain itu, sinergitas regulasi antara pusat dan daerah masih perlu dipersiapkan dengan matang. Ketidakmerataan distribusi pendapatan di berbagai wilayah tersebut menyebabkan munculnya ketimpangan ekonomi yang berakibat pula ketimpangan di bidang lainnya.

Ketimpangan dalam ekonomi memunculkan dua sisi. Pertama, orang yang berpendapatan besar yang disebut dengan orang kaya. Kedua, orang yang berpendapatan kecil dan bahkan kurang yang disebut dengan orang miskin. Kondisi ini seperti menurut Ferreira dalam Waluyo (2004) bahwa orang yang masuk dalam golongan miskin, tidak mempunyai kesempatan hidup yang sama dibandingkan dengan orang kaya. Akibatnya, mereka tidak pernah bisa merealisasikan 
semua produktivitas potensialnya. Penyebabnya adalah keterbatasan mereka dalam mengakses pendidikan yang layak dan tinggi. Selain itu, kondisi juga dipengaruhi adanya keterbatasan akses layanan kredit untuk memulai usaha dagang.

Akibatnya, banyak orang yang termasuk dalam golongan miskin hanya dapat melakukan pekerjaan-pekerjaan informal dan serabutan. Keadaan seperti ini tentu bukan kondisi yang baik bagi mereka yang sudah berkeluarga. Hal ini karena akan memengaruhi ketahanan keluarga mereka. Anakanak mereka pun pada akhirnya ikut menjadi korban situasi ini. Beberapa di antara mereka pun memutuskan untuk hidup di jalan sebagai anak jalanan.

Kemunculan anak-anak yang hidup di jalan menjadi fenomena yang sering kita saksikan. Keberadaan mereka sangat mudah ditemukan. Biasanya, mereka akan mudah ditemukan di kota-kota besar dan/atau di daerah yang mempunyai ketimpangan sosial-ekonomi yang tinggi.

UNICEF mencatat bahwa di seluruh dunia terdapat sekitar 150 juta anak yang hidup di jalan. Kemunculan anak jalanan ini terbanyak ditemukan di negara-negara berkembang. Namun, kondisi ini tidak menutup kemungkinan muncul pula di kota-kota besar negara maju. Lalu, bagaimana dengan kondisi anak jalanan di Indonesia?

Dalam Survei Sosial Ekonomi Nasional (SUSENAS) Badan Pusat Statistik (BPS) Republik Indonesia tahun 1998 memperlihatkan bahwa anak jalanan secara nasional berjumlah sekitar 2,8 juta jiwa. Dua tahun kemudian, yaitu tahun 2000, angka tersebut mengalami kenaikan sekitar 5,4\%. Dengan demikian, jumlah anak jalanan meningkat menjadi 3,1 juta anak. Pada tahun yang sama, anak yang tergolong rawan menjadi anak jalanan berjumlah 10,3 juta anak atau 17, 6\% dari populasi anak di Indonesia, yaitu 58,7 juta anak (Soewignyo, 2002). 
Kemudian, jika melihat data Pusdatin Kesejahteraan Sosial Tahun 2010 menyebutkan bahwa pada 2009 populasi anak jalanan di Indonesia mencapai 85.013 jiwa. Jumlah ini berasal dari penyebaran di semua provinsi di Indonesia. Namun, jika dilihat dari urutan sepuluh besar, berikut adalah rinciannya: Nusa Tenggara Barat (12.764), Nusa Tenggara Timur (12.937), Jawa Tengah (8.027), Jawa Timur (7.872), Jawa Barat (4.650), Sulawesi Tengah (4.636), Banten (3.902), Sumatra Barat (3.353), Maluku (2.899), dan Lampung (2.799).

Kemudian, pada data yang dihimpun sampai Agustus 2017, Pusat Data dan Informasi Kesejahteraan Kementerian Sosial mencatat jumlah anak jalanan sebanyak 16.290. Jumlah ini dapat dikatakan sudah turun secara signifikan karena jumlah anak jalanan pada 2006 adalah 232.894 orang. Kemudian, pada 2010 turun menjadi 159.230 anak. Angka tersebut turun menjadi 67.607 anak pada 2011. Lalu, pada 2015 turun menjadi 33.400 anak. Jumlah anak jalanan tersebut tersebar pada 21 provinsi di Indonesia.

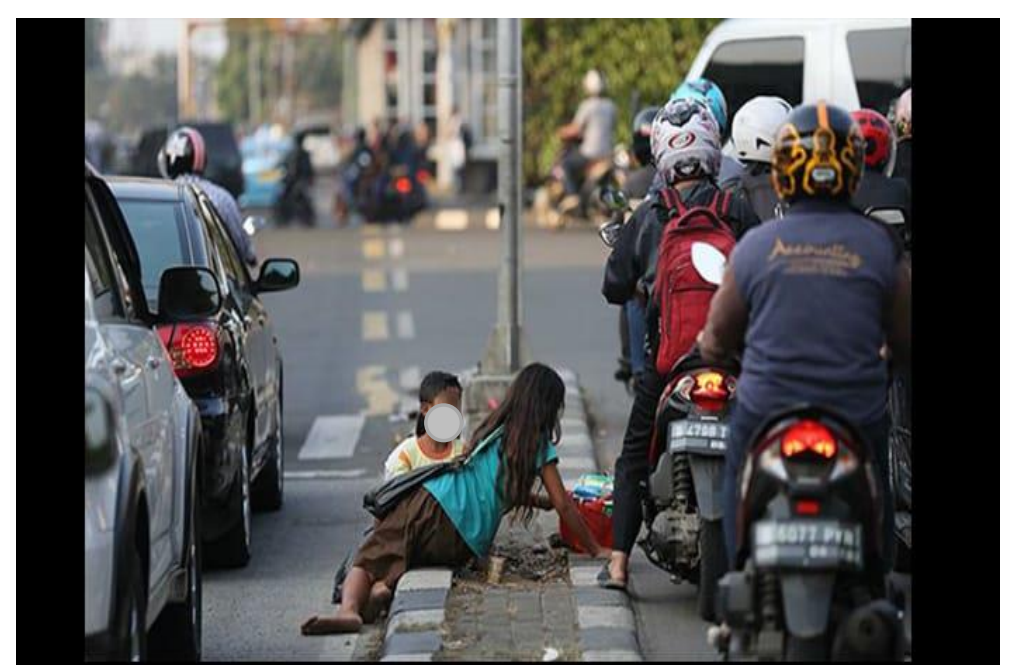

Anak jalanan berjualan tisu.

Sumber: https://bit.ly/3koAdz3 
Meskipun dari tahun ke tahun jumlah anak jalanan sudah mengalami penurunan, masalah anak jalanan masih menjadi pekerjaan rumah yang belum selesai. Hal ini harus menjadi perhatian semua pihak karena anak-anak ini mempunyai hak sama dengan anak lainnya. Jika kita telaah lebih jauh, masalah yang melingkupi anak-anak jalanan sangatlah kompleks. Berikut adalah beberapa contoh masalah krusial yang mereka hadapi sehari-hari.

\section{Pendidikan}

Masih adanya ketimpangan sosial ekonomi di berbagai wilayah, menyebabkan pendidikan pun belum merata. Masih banyak anak Indonesia yang tidak bersekolah dan atau putus sekolah. Pada dasarnya, banyak faktor yang dapat menjadi sebab mengapa anak-anak tidak bersekolah atau bahkan putus sekolah. Namun, berdasarkan studi yang dilakukan Yayasan Sayangi Tunas Cilik (STC), setidaknya terdapat dua penyebab terbesar. Keduanya adalah kemiskinan dan pernikahan dini.

Dilansir dari Tempo.co, data yang dihimpun oleh Tim Nasional Percepatan Penanggulangan Kemiskinan (TNP2K) pada 2019 mencatat bahwa secara nasional terdapat 4,5 juta anak yang putus sekolah. Anak-anak dengan rentang usia 7-12 tahun yang tidak sekolah mencapai 1.223.792 anak. Sementara itu, dalam rentang usia 13-15 tahun yang tidak bersekolah berjumlah 936.674 anak. Kemudian, untuk rentang usia 16-18 tahun mencapai 2.420.866 anak. Provinsi Jawa Barat mempunyai jumlah terbanyak karena mencapai 958.599 anak. Provinsi lain di posisi kedua dan ketiga adalah Jawa Tengah dan Jawa Timur.

Di dalam data-data tersebut, anak-anak jalanan pun tercatat. Oleh karena berbagai keterbatasan, mereka tidak dapat merasakan proses belajar formal di sekolah. Ada beberapa penyebab mereka memutuskan untuk tidak melanjutkan sekolah. Pertama, faktor ekonomi. Penghasilan orang tua yang hanya cukup untuk memenuhi kebutuhan hidup sehari-hari menjadi pemicunya. Kedua, faktor lebih 
senang di jalan. Ketika mereka di jalanan, mereka sangat menikmati karena tidak mempunyai tanggungan untuk belajar seperti anak-anak yang lain. Oleh karena desakan ekonomi sehingga mereka akhirnya mencari uang di jalanan dan ada rasa senang mendapatkan uang, mereka pun lupa untuk melanjutkan proses pendidikan di sekolah.

Namun demikian, ada beberapa anak jalanan yang ternyata masih bersekolah. Meskipun hal ini boleh dikatakan sebuah hal positif, mereka pun memerlukan perhatian. Oleh karena itu, perlu dicari sebuah jalan keluar agar mereka bisa bersekolah dengan baik, tanpa harus turun ke jalan. Hal ini berkaitan dengan kekhawatiran kehidupan di jalanan yang dapat mengganggu proses belajar mereka. Misalnya, mulai pemahaman terhadap pelajaran sampai ke prestasi di sekolah yang tidak dapat maksimal.

\section{Eksploitasi ekonomi}

Eksploitasi ekonomi yang terjadi pada anak-anak jalanan dapat berupa mengemis, mengamen, berjualan asongan, menyemir sepatu, menjajakan tisu, dan lain sebagainya. Eksploitasi ini dapat dilakukan oleh orang tua dan preman di jalanan. Dalam hal ini, preman merampas hasil yang diperoleh anak jalanan setelah mengamen, berjualan, dan lain sebagainya.

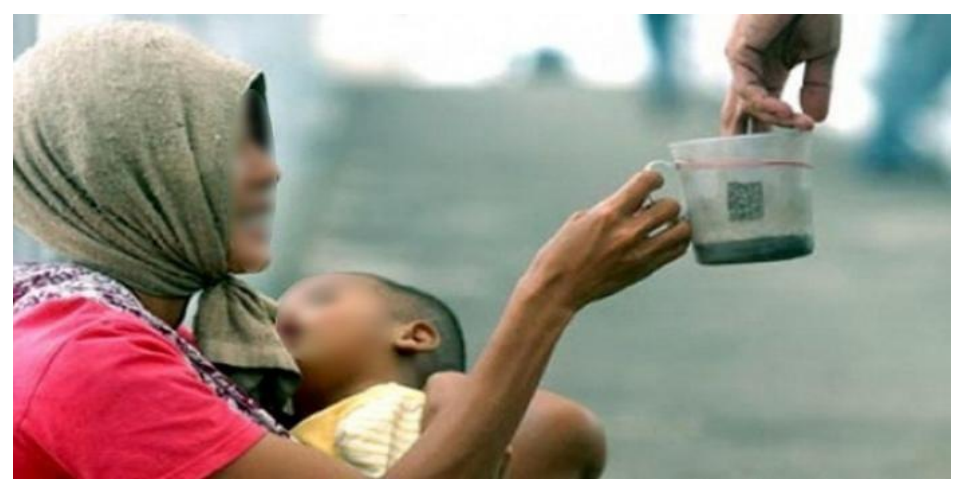

Anak-anak diajak untuk mengemis.

Sumber: $\underline{\text { ttps://bit.ly/2ZLlbvp }}$ 


\section{Kekerasan}

Kekerasan, baik fisik, psikis, dan seksual masih banyak terjadi di masyarakat. Tidak hanya orang dewasa, anak-anak dan anak perempuan pun rentan mengalami berbagai kekerasan ini. Dalam penelitian yang dilakukan Rustanto (2014), data Komisi Nasional Perlindungan Anak (Komnas PA), selama 2009 terjadi 736 kasus. Sebanyak 327 kasus merupakan kekerasan. Lalu, sebanyak 233 kasus merupakan kekerasan fisik. Sisanya, sebanyak 176 kasus merupakan kekerasan psikis.

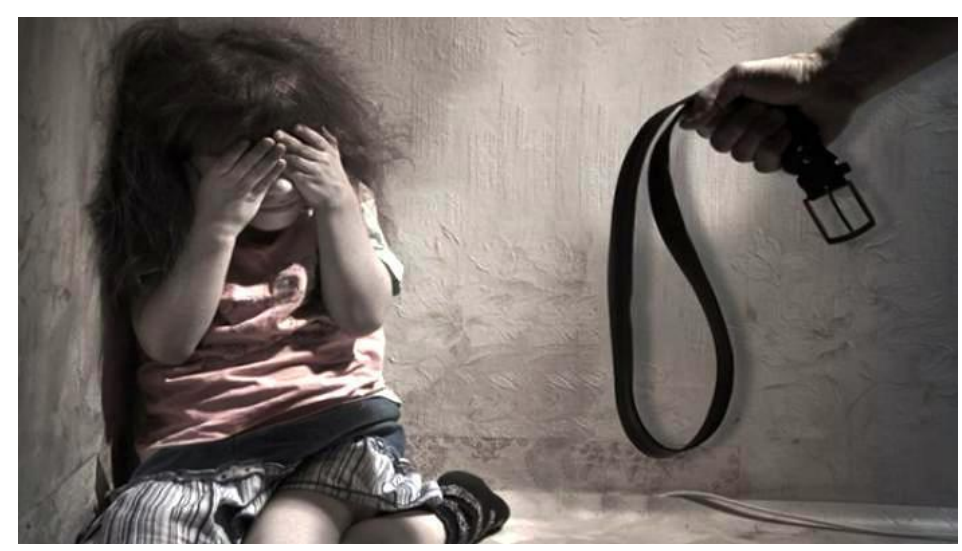

Kekerasan terhadap anak masih sering terjadi.

Sumber: https://bit.ly/3iEczOu

Sementara itu, berdasarkan data yang dihimpun oleh Komnas Perempuan, diperoleh data bahwa pada 2017 kasus kekerasan pada anak perempuan mencapai 2.227 kasus. Pada 2018, kasus yang tercatat adalah 1.417 kasus. Pada 2019, kekerasan terhadap anak perempuan melonjak menjadi 2.341 kasus. Kekerasan terhadap anak perempuan banyak terjadi di ranah domestik dan relasi personal.

Komnas Perempuan (dalam CATAHU 2020), mencatat setidaknya tempat terjadinya kekerasan ada tiga ranah. Pertama, ranah domestik. Kekerasan dalam ranah ini dilakukan oleh orang yang memiliki hubungan darah, kekerabatan, perkawinan, dan relasi intim dengan korban. 
Kedua, ranah publik atau komunitas. Pelaku yang termasuk dalam ranah ini, misalnya, majikan, tetangga, guru, tokoh masyarakat, dan orang yang tidak dikenal. Ketiga, ranah negara.

Namun, poin yang perlu juga diperhatikan adalah bahwa kekerasan seksual terhadap anak tidak hanya terjadi pada anak perempuan. Akan tetapi, situasi ini rawan terjadi pula pada anak laki-laki. Hal ini pun tak luput pula mengancam anak-anak jalanan yang jauh dari pengawasan orang tua dan orang dewasa sekitarnya.

Pada 2012, KPAI mencatat jumlah kekerasan yang terjadi pada anak jalanan secara nasional mencapai $15 \%$ dari 2.636 kasus. Jumlah kasus meningkat menjadi 3.039 pada 2014. Sementara itu, kota yang memiliki angka kasus kekerasan seksual terhadap anak jalanan tertinggi adalah Jakarta.

Menurut Komisioner Bidang Sosial dan Anak dalam Situasi Darurat Komisi Perlindungan Anak Indonesia (KPAI), alasan para pelaku perdagangan manusia menjadikan anak jalanan sebagai korban adalah karena mudah dipengaruhi. Hal itu karena anak jalanan diimingimingi mendapatkan uang dengan mudah. Hal ini lagi-lagi berhubungan dengan faktor ekonomi dan kurangnya bimbingan dari keluarga.

Namun, dalam penelitian yang dilakukan Pusat Penelitian HIV-AIDS Atmajaya, Jakarta, anak-anak jalanan ini pun sering melakukan tindakan seksual yang berisiko di kalangan mereka sendiri. Penelitian yang dilakukan di Jakarta menunjukkan bahwa sebagian anak jalanan yang berusia dewasa akan memaksa anak-anak di bawah umur mereka sebagai pelampiasan hasrat seksualnya. Perilaku ini tentu sangat berisiko bisa terkena HIV.

Kondisi ini menjadi bukti bahwa ancaman kekerasan seksual bagi anak jalanan dapat berasal dari mana saja. Bisa berasal dari lingkungan keluarga, orang-orang yang ditemui di jalan, dan rekan sesama anak jalanan. Namun, yang 
menjadi keprihatinan kita bersama adalah kebanyakan anak jalanan tidak mengerti perilaku seksual berisiko dan kesehatan reproduksi. Bahkan, mereka tidak mengetahui perrilaku apa saja perilaku yang termasuk tindakan kekerasan, termasuk kekerasan seksual. Mereka pun tak pernah melaporkan kasus kekerasan seksual.

\section{Minuman Keras dan Narkoba}

Ancaman berikutnya adalah minuman keras dan penyalahgunaan narkoba. Oleh karena kehidupan di jalanan yang bebas tanpa pengawasan orang tua, mereka sangat rentan untuk terpengaruh kedua hal ini. Kebiasaan anak jalanan mengonsumsi minuman keras patut menjadi perhatian. Dalam penelitian yang dilakukan oleh Solecha (2017), ditemukan bahwa sebagian anak jalanan adalah pengonsumsi alkohol. Meskipun demikian, banyak dari mereka justru tidak tahu-menahu tentang alkohol. Hal ini dapat diasumsikan bahwa mereka hanya ikut-ikutan teman lainnya. Kondisi ini tentu sangat berbahaya karena mereka tidak mengetahui dampak dari konsumsi alkohol.

Dalam tataran yang lebih berbahaya, anak-anak jalanan rentan terhadap penyalahgunaan narkoba. Hasil penelitian yang dilakukan oleh tiga murid SMA Tarakanita I Jakarta pada 2008, ditemukan bahwa hampir semua anak jalanan pernah mencoba mengonsumsi ganja, lem aibon, thinner cat, dan lain sebagainya. Dalam penyelidikan lainnya, ditemukan alasan mengapa anak-anak jalanan menghirup lem aibon. Alasan yang mereka ungkapkan adalah karena dapat membuat merasa lebih kenyang.

Sementara itu, di beberapa kota besar, anak-anak jalanan pun dijadikan kurir narkoba. Modus yang digunakan para pengedar adalah menyuruh mereka untuk mengantarkan bungkusan barang haram ini kepada seseorang pembeli dengan imbalan uang. Uang yang diperoleh anak-anak jalanan yang menjadi kurir ini pun tidak main-main. Dalam lansiran data Duta.co, ada anak 
yang mendapatkan imbalan 7-14 juta. Meskipun tampak menguntungkan karena uang yang didapat sangat banyak, kondisi ini sangat membahayakan untuk mereka.

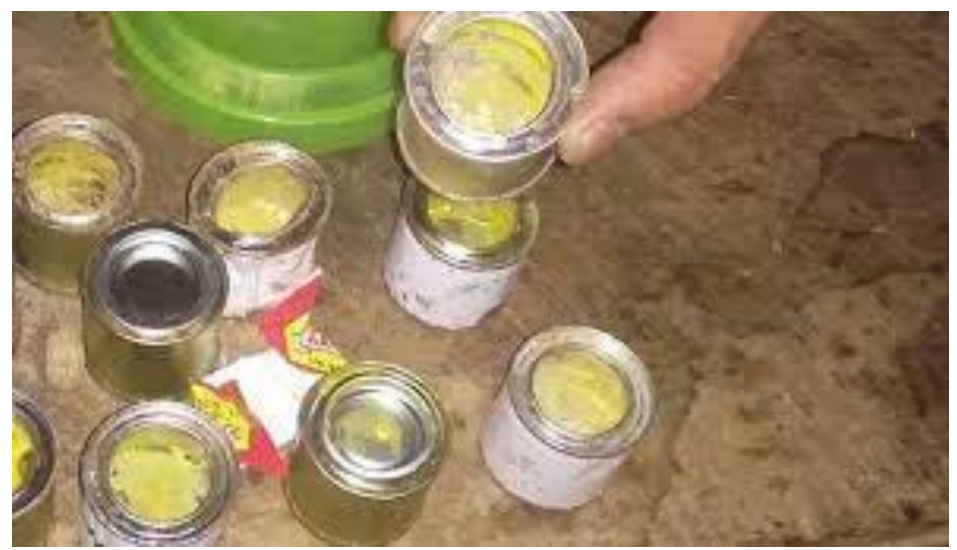

Lem Aibon sering digunakan untuk mabuk anak-anak jalanan.

Sumber: $h t t p s: / / b i t . l y / 3 m r m p p t$

Selanjutnya, studi tentang fenomena anak jalanan telah banyak dilakukan di beberapa kota. Dalam penelitian tentang anak jalanan di Balikpapan ditemukan bahwa terdapat beberapa faktor yang menyebabkan anak-anak menjadi anak jalanan. Faktor-faktor tersebut adalah adalah faktor ekonomi, faktor pendidikan yang rendah baik dari orang tua maupun anak, dan kesadaran pribadi si anak yang ingin membantu orang tua. Aktivitas yang mereka lakukan sehari-hari adalah beragam. Misalnya, dari pagi hari hingga petang berjualan koran, pengemis, pengamen di jalanan, buruh angkut di pasar, dan ada juga anak yang bekerja sebagai pengamen dan tukang minta-minta di area tempat hiburan warga kota Balikpapan di malam hingga dini hari (Purwoko, 2013).

Sementara itu, penelitian yang dilakukan oleh Pirngadi (2007) difokuskan di kawasan JABODETABEK. Dalam penelitiannya, dapat dipetakan akar permasalahan anak jalanan adalah karena adanya desakan ekonomi keluarga. Selain itu, 
faktor rendahnya pendidikan orang tua dan rumah tinggal yang kumuh juga menjadi penyebabnya. Di pihak lain, perlindungan dari para pemangku kebijakan di wilayah setempat belum tampak. Hal ini kemudian diperparah dengan belum optimalnya social control masyarakat dan peran dari lembaga-lembaga organisasi sosial.

Melihat data-data dan berbagai masalah tersebut dapat ditarik kesimpulan bahwa penanganan masalah anak jalanan memerlukan upaya yang serius. Dalam usaha menangani masalah-masalah ini, pada dasarnya kunci utama terletak pada peran keluarga. Hal ini karena keluarga menjadi basis dan sistem solusi penyelesaian masalah. Keluarga adalah pilar utama kehidupan berbangsa dan bernegara. Jika sebuah keluarga mempunyai basis yang kuat, masyarakat dan negara pun akan bertumbuh menjadi sehat, kuat, cerdas, dan berkualitas.

Namun, dalam kenyataannya, perhatian dan treatment yang terfokus pada keluarga belum menjadi komitmen bersama. Oleh karena itu, perlu adanya usaha bersama dari berbagai pihak, mulai dari para pemangku kebijakan di pusat dan daerah, para pemerhati masalah sosial, serta masyarakat luas agar dapat menguatkan keluarga yang belum mempunyai basis kuat ini. Dengan harapan, anak-anak jalanan ini terlepas dari risiko ancaman di jalanan. Lebih jauh, harapannya adalah jumlah anak jalanan dapat ditekan sampai tidak ada lagi anak yang harus hidup di jalan.

\section{B. Anak Jalanan dalam Perspektif Teoretis}

Dalam upaya untuk mengulik fenomena kemunculan anak jalanan umumnya, dan anak jalanan di kota Cirebon pada khususnya, beberapa konsep dasar yang saling berkaitan perlu diulas terlebih dahulu. Konsep pertama yang harus dipahami adalah tentang analisis sosial. Kemudian, definisi anak di mata undang-undang. Lalu, konsep anak jalanan dari berbagai sumber harus ditelaah pula. Hal ini sangat penting dipahami 
agar kita mengetahui bagaimana sebenarnya latar belakang kemunculan anak jalanan.

Selanjutnya, sebagaimana telah disebutkan bahwa kunci utama penyelesaian masalah anak adalah keluarga maka pemahaman tentang konsep ketahanan keluarga tidak boleh terlewatkan. Kemudian, satu aspek yang juga perlu menjadi perhatian adalah mengenai teori Tindakan. Teori ini berkaitan dengan keputusan-keputusan yang diambil anak-anak untuk hidup di jalanan karena berbagai latar belakang kehidupan keluarga, ekonomi, dan lain sebagainya.

\section{Teori Analisis Sosial}

Secara umum, teori analisis sosial diartikan sebagai usaha untuk memperoleh gambaran lebih lengkap tentang situasi sosial secara objektif dan kritis dengan mengkaji berbagai hubungan struktural, kultural, dan historis. Pengkajian analisis sosial akan fokus dalam memahami fenomena-fenomena sosial yang dikaitkan dengan aspek politik, ekonomi, budaya, dan agama. Hal ini bertujuan untuk mengetahui sejauhmana perubahan sosial itu terjadi. Selain itu, untuk mengetahui bagaimana institusi sosial yang menyebabkan munculnya masalah sosial dan dampak yang ditimbulkannya.

Masalah sosial diartikan sebagai sebuah kondisi yang menjadi akibat dari ketidaksesuaian antara impian dan kenyataan dalam hidup bermasyarakat sehingga terjadi penyimpangan atau interaksi sosial yang menyimpang. Menurut Soetomo, masalah sosial adalah suatu keadaan yang berbeda dengan kehidupan biasanya yang sering kali tidak diinginkan masyarakat secara umum dan mengakibatkan gejolak-gejolak sosial. Kondisi ini dapat menimbulkan penderitaan dan kerugian, baik fisik maupun nonfisik. Kemudian, Weinberg mempunyai titik fokus bahwa masalah sosial muncul sebagai akibat dari latar belakang yang bertentangan dengan nilai dan norma mayoritas yang berlaku di masyarakat. Pertentangan 
tersebut menimbulkan adanya proses perubahan sosial yang signifikan.

Sementara itu, sebagaimana pendapat Soetomo, Soekanto menambahkan bahwa masalah sosial muncul sebagai akibat dari ketidaksesuaian kehidupan dalam kehidupan masyarakat karena adanya pengaruh kebudayaan atau rutinitas yang terganggu. Hal ini kemudian menyebabkan masalah sosial dianggap sebagai keadaan yang menakutkan. Setidaknya, terdapat empat faktor penyebab munculnya sebuah masalah sosial.

Pertama, faktor ekonomi. Faktor ini menyebabkan masalah sosial seperti kemiskinan dan pengangguran. Kondisi ini menimbulkan berbagai dampak seperti tindakan kriminalitas untuk memenuhi kebutuhan hidup. Kemiskinan muncul dapat diakibatkan minimnya pekerjaan yang disediakan pemerintah. Oleh karena itu, perlu adanya perhatian dari pemerintah untuk dapat memberikan berbagai alternatif ksempatan ekonomi yang merata bagi semua masyarakat. Hal ini menjadipenting karena ekonomi dapat menjadi acuan kemajuan sebuah negara. Selain itu, faktor ini berhubungan serat dengan dua aspek lainnya, yaitu aspek biologis dan psikologis di masyarakat.

Kedua, faktor biologis. Faktor ini berhubungan dengan kesehatan. Misalnya, adanya wabah penyakit, kurang gizi, dan lain sebagainya. Kondisi ini bisa terjadi karena fasilitas kesehatan yang kurang memadai. Lalu, diperparah dengan rendahnya kondisi ekonomi dan pendidikan masyarakat. Kondisi ekonomi, misalnya, berhubungan dengan ketidakmampuan masyakarat untuk memenuhi kebutuhan gizi dan mengakses layanan kesehatan. Sementara itu, kondisi pendidikan dihubungkan dengan keterbatasan pengetahuan masyarakat tentang kesehatan. Misalnya, pengetahuan tentang pola hidup sehat, cara mengakses layanan kesehatan, dan lain sebagainya. 
Ketiga, faktor psikologis. Faktor psikologis muncul sebagai akibat dari ketidakmampuan masyarakat dalam memikul beban hidup yang dirasakan. Jika kondisi ini dibiarkan tanpa sebuah solusi, ketika emosi masyarakat memuncak akan dapat memicu munculnya berbagai konflik di masyarakat.

Keempat, faktor kebudayaan. Faktor ini mempunyai makna bahwa budaya berperan dalam memicu munculnya permasalahan sosial. Misalnya, pernikahan dini, kenakalan remaja, perceraian, penyalahgunaan narkoba, dan lain sebagainya. Faktor kebudayaan harus menjadi perhatian serius dan penanganan yang tepat karena budaya merupakan cerminan dari tradisi dan kebiasaan suatu masyarakat.

Berikut adalah beberapa contoh masalah yang sering terjadi di masyarakat.

a. Kemiskinan

Seseorang disebut miskin ketika dia tidak sanggup untuk memelihara dirinya sendiri sesuai dengan taraf kehidupan kelompok atau masyarakat. Kondisi ini juga berkaitan dengan ketidakmampuan orang tersebut dalam memanfaatkan mental dan fisiknya dalam kelompok masyarakat tersebut.

Awalnya, kondisi miskin dan kaya seseorang tidak menjadi masalah sosial hingga adanya perdagangan yang pesat dan menimbulkan nilai-nilai baru di masyarakat. Perdagangan tersebut kemudian menetapkan taraf hidup tertentu sehingga menciptakan sebuah masalah sosial.

b. Kejahatan

Kejahatan dapat muncul karena adanya proses imitasi pelaksanaan peran sosial, kompensasi, asosiasi diferensiasi, konsep diri, identifikasi, dan kekecewaan yang agresif. Seseorang dapat mempunyai perilaku jahat karena belajar melalui pergaulannya dengan pelaku kejahatan. 
c. Disorganisasi keluarga

Disorganisasi keluarga diartikan sebagai kondisi keluarga yang mengalami perpecahan karena setiap anggota keluarga tersebut gagal dalam memenuhi kewajiban sesuai dengan peranan sosialnya. Masalah disorganisasi keluarga menjadi masalah yang sangat pelik. Hal ini karena berhubungan dengan berbagai faktor. Misalnya, ekonomi, psikologis, pendidikan, agama, dan lain sebagainya. Contoh dari disorganisasi keluarga adalah komuikasi yang buruk antaranggota keluarga, perceraian, hilangnya pemimpin rumah tangga, dan terganggunya keseimbangan jiwa dari salah satu anggota keluarga.

d. Masalah generasi muda

Masalah yang muncul pada generasi muda ditandai dengan adanya dua jenis perlawanan. Pertama, melawan yang ditunjukkan dalam perliaku radikalisme. Kedua, sikap apatis yang ditunjukkan dengan penyesuaian membabi buta terhadap ukuran moral dari generasi tua.

Kedua bentuk perlawanan ini merupakan respons anak-anak muda terhadap sikap generasi tua yang tidak memberikan kesempatan pada mereka untuk membuktikan kemampuan yang dimiliki. Kondisi ini diperparah dengan kurangnya perhatian generasi tua terhadap anak-anak mereka. Hal ini terutama sekali tampak di kehidupan masyarakat perkotaan. Akibat dari pelakukan ini, muncul masalah-masalah sosial seperti kurangnya rasa percaya diri anak dan munculnya kelompok pemuda informal yang mempunyai perilaku tidak disukai di masyarakat. Selain itu, dapat memunculkan usaha-usaha para generasi muda untuk mengadakan perubahan dalam masyarakat sesuai dengan nilai-nilai yang mereka miliki. 
e. Perang

Perang diartikan sebagai sebuah pertentangan antara kelompok atau masyakarat, termasuk negara, yang biasanya diakhiri dengan suatu akomodasi. Oleh karena peperangan selalu melibatkan berbagai kelompok atau masyakarat dari berbagai lapisannya maka dapat menyebabkan disorganisasi dalam berbagai aspek di masyarakat.

f. Pelanggaran terhadap norma

Pelanggaran terhadap norma dapat diakibatkan karena kurangnya pemahaman seseorang terhadap norma yang berlaku di masyarakat. Namun, kondisi ini sering pula dipengaruhi oleh berbagai aspek lainnya. Misalnya, ekonomi, pendidikan, psikologis, urbanisasi, dan lain sebagainya. Beberapa contoh dari masalah ini adalah adanya pelacuran, alkoholisme, dan kenakalan remaja. Pelacuran adalah masalah yang meresahkan masyarakat karena dapat merusak moral, mental, dan keutuhan keluarga. Sementara alkoholisme berkaitan dengan akibat dari konsumsi alkohol yang mengganggu ketertiban di masyarakat. Selanjutnya adalah kenakalan remaja yang biasanya ditandai dengan perilaku beberapa anak yang tidak disukai oleh masyarakat. Misalnya, kebut-kebutan, tawuran, meminta-minta uang secara paksa, dan lain-lain.

Dengan berbagai gambaran masalah yang telah diperoleh tersebut maka sebuah analisis sosial dipandang perlu. Hal ini karena dapat digunakan untuk mengindentifikasi akar dan percabangan masalah sosial dengan saksama. Dengan pemahaman tersebut, nantinya dapat dilihat potensi apa saja yang dimiliki oleh kelompok atau masyarakat yang menjadi objek kajian. Hal ini kemudian akan dapat menunjukkan bahwa objek yang dinilai sebagai masalah sebenarnya mempunyai sisi nilai positif yang bisa dikembangkan ke arah yang lebih baik. 